ISSN1027-5495. Functional Materials, 23, No.3 (2016), p. 496-501

doi:http://dx.doi.org/10.15407/fm23.03.496

(C) 2016 - STC “Institute for Single Crystals"

\title{
Studying on plasma acid using in hemp degumming process
}

\author{
Wang Ying ${ }^{1}$, Yin $\mathrm{Di}^{2}$, Ji Yingchao ${ }^{1}$, Zhang Qingli ${ }^{2}$, Yu Zhihua ${ }^{2}$, \\ Li Hong ${ }^{1}$, Wang Qiuhong ${ }^{1}$
}
${ }^{1}$ School of textile and material engineering, Dalian Polytechnic University, No.1 Qinggong Yuan, Ganjingzi District, Dalian, Liaoning, China
${ }^{2}$ Dalian Hualong filter cloth co., LTD, Dalian, Liaoning, China

\section{Received April 22, 2016}

The purpose of this study is to provide a green agent for hemp degumming process. In the study, plasma acid was collected by processing distilled water with dielectric barrier discharge device under atmospheric pressure. Then the plasma acid was used in hemp degumming process. The facilities and instruments required in the whole procedure were easy operation and low cost. In this experiment, bath ratio, temperature and processing time were main factors. The optimal scheme of plasma acid degumming process was proposed through orthogonal experiment. The results of the pectin and lignin removal rate tests revealed that plasma acid was effective in hemp degumming process. After plasma acid treatment, the content of pectin and lignin was decreased by $58.553 \%$ and $43.70 \%$, respectively. After plasma acid treatment, the cellulose structure of hemp fiber has not been changed by the XRD analysis. Lots of single fibrils were clearly seen in the SEM images.

Keywords: Hemp fiber, plasma Acid, degumming processing

Целью данного исследования является создание зеленого агента для процесса дегуммирования пеньки для использования ее в фрармакологии. Предложена оптимальная схема процесса дегуммирования пеньки плазменной кислотой. Результаты испытаний по определению скорости удаления пектина и лигнина подтвердили эффрективность плазменной кислоты при дегуммировании пеньки. После обработки плазменной кислотой содержание пектина и лигнина уменьшилось на $58.553 \%$ и $43,70 \%$, соответственно. По данным рентгенофразового анализа структура целлюлозы из волокна пеньки после обработки плазменной кислотой не изменилась. Множество одиночных фрибрилл были отчетливо видны на снимках SEM.

Вивчення використання плазмової кислоти для дегумування пеньки. $B a н$ I Інь Ді, Цзи Інг Чао, Чжан Цин Лі, Лі Хун, Ван Цю Хун

Метою даного дослідження є створення зеленого агенту для процесу дегумування пеньки. Запропоновано оптимальну схему процесу дегумування пеньки плазмової кислотою для використання її у фармакології. Результати випробувань з визначення швидкості видалення пектину і лігніну підтвердили ефрективність плазмової кислоти під час дегумування пеньки. Після обробки плазмової кислотою вміст пектину і лігніну зменшився на 58.553\% і 43,70\%, відповідно. За даними рентгенофазового аналізу структура целюлози з волокна пеньки після обробки плазмової кислотою не змінилася. Велика кількість поодиноких фібрил чітко видна на знімках SEM.

\section{Introduction}

Cotton and synthetic fiber can meet most of the world's textile needs. However, their productive processes could cause multiple en- vironmental problems. Synthetic fiber products deplete fossil energy resources, while cotton cultivation is characterized by high water requirements as well as substantial amounts using of fertilizers and pesticides. Products made 
of hemp fiber have high permeability, good water absorption, and better anti-bacterial properties, which gained popularity around the world. In addition, during the growth of hemp, no fertilizers and pesticides are needed, which is friendly to environment $[1,2]$. Hemp as a non-cotton natural fiber will contribute greatly to the sustainable development of the textile industry [3-5].

In order to improve the spinning quality of hemp fiber and the performance of hemp products, the gummy substance of hemp fiber should be removed partly, which is called degumming. Degumming is a key process in hemp textile production. The pectin and lignin are main components of the gummy substance. The fewer pectin and lignin content, the better hemp fiber qualification. Research on hemp textiles are fewer than flax and ramie. Thus the hemp textile industries prefer to follow similar or identical technologies that used for flax and ramie. Nevertheless, the lignin content of hemp is higher than flax and ramie. Therefore, hemp degumming process is more difficult than those two materials.

Chemical method is effective, especially in the case of removal of lignin, and is widely used in hemp degumming process. Unfortunately, the chemical method has many disadvantages such as environmental pollution, and difficulties in removing the residual chemical substance from the degummed fiber. As a result, since the green awareness and concern about the environment increased, an eco-friendly degumming method is being researched. Recently, large numbers of degumming methods have been studied, which can be summed up as mechanical and biological technology. Among these methods, chemical agents also have to be used to improve the degumming effect, which still could do harm to the environment.

In this article, plasma acid was prepared and then used in hemp degumming procedure. Moreover, sulfuric acid $\left(\mathrm{H}_{2} \mathrm{SO}_{4}\right)$ processing hemp was carried out as a contrast experiment. Moreover, the experimental results of plasma acid degumming were discussed. The surface structure of hemp fiber treated by plasma acid were also investigated by X-ray diffractometr (XRD), scanning electron microscopy (SEM)

\section{Materials and methods}

\subsection{Materials}

The experimental material was Longjiang1\# raw hemp from China. The main chemical component of this fiber is shown in Table 1. The component analysis reagents were ethylene diamine tetraaceticacid (EDTA) from Srnopharm
Table 1. Main component of the raw hemp fiber

\begin{tabular}{|c|c|c|c|c|}
\hline Items(\%) & Pectin & $\begin{array}{c}\text { Hemi-cel- } \\
\text { lulose }\end{array}$ & Lignin & $\begin{array}{c}\text { Cellu- } \\
\text { lose }\end{array}$ \\
\hline Content & 14.07 & 28.86 & 7.17 & 49.91 \\
\hline
\end{tabular}

Chemical Reagent Co., Ltd and $\mathrm{H}_{2} \mathrm{SO}_{4}$ from Tianjin Kemiou Chemical Reagent Co., Ltd. Both of them were reagent grade.

\subsection{Methods}

\subsubsection{Preparing of plasma acid}

Plasma is a partially or fully ionized gas consisting of electrons, free radicals, ions and neutrals. All varieties of plasma systems are traditionally defined into two major categories, namely thermal and non-thermal, in terms of electronic density and temperature. Thermal plasma (usually arc discharges, torches or radio frequency) is associated with sufficient energy introduced to allow plasma constituents to be in thermal equilibrium. While non-thermal plasma is obtained using less power (usually corona discharge, dielectric barrier discharge, gliding arc discharge, glow discharge and spark discharge). As for non-thermal plasma, it does not express a local thermodynamic equilibrium, which, therefore, offers high selectivity and energy efficiency in plasma chemical reactions [6-7]. The equipment required in plasma acid preparation in this paper was dielectric barrier discharges plasma (DBD). DBD plasma has got large-scale application in industry [8-12].

In this paper, plasma acid was collected by processing distilled water using DBD device under atmospheric pressure [13], showed in Fig. 1. After plasma processing, water molecules would dissociate protons and electrons. The protons accumulated under the action of an electric field. Thus, the processed water had the characteristic of acid [11]. The acidity of plasma acid was controlled by discharge power and pump rotational speed. When pump rotational speed was ranged from 4.2 to $8.2 \mathrm{r} / \mathrm{min}$ under $80 \mathrm{~W}$ discharge power, plasma acid with $\mathrm{pH}$ value from 3.6 to 1.4 was produced. In this article, $\mathrm{pH} 2.6$ plasma acid was used in hemp degumming experiment.

\subsubsection{Degumming of hemp}

The experiments were all carried out under atmospheric pressure. First of all, the hemp fiber was immersed in plasma acid. Then the hemp fiber was boiled in JRA - 6 digital magnetic stirring water bath pot. Finally, the hemp fiber was washed and dried at $60{ }^{\circ} \mathrm{C}$.

During plasma acid degumming, bath ratio, temperature and processing time were the main factors. In order to study the effectiveness 


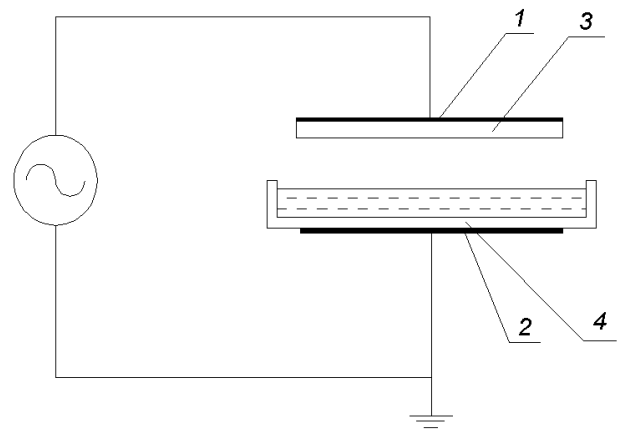

Fig. 1. The chart of plasma reactor: 1and 2 electrodes, 3 and 4 barriers

of plasma acid, the parameters of these factors were set in Table 2. The orthogonal experiment was designed by different parameters, and the result was evaluated by pectin and lignin removal rate. The optimal scheme of plasma acid processing hemp was determined through the orthogonal experiment. Under the same condition, $\mathrm{H}_{2} \mathrm{SO}_{4}$ processing hemp was carried out as a contrast experiment.

\subsubsection{Hemp chemical components analysis}

The chemical components analysis of plasma acid treated hemp was listed as follows.

Pectic acid and its derivatives were degradable in the EDTA liquor, while other components of hemp yefiber were not. The pectin content was tested with this method. Each specimen weighed $1.2 \pm 0.010 \mathrm{~g}$ was tested 3 times. Samples were dried to constant weight at $105 \pm 3{ }^{\circ} \mathrm{C}$, and then the weight of the dried samples were tested and recorded as $\mathrm{W}_{1}$. Each dried sample was immersed into $60 \mathrm{ml} 0.5 \%$ EDTA liquor, boiled in the YX series porTable pressure steam sterilizer at $105 \pm 1^{\circ} \mathrm{C}$ for $50 \mathrm{~min}$, and then taken out. After filtering, the residue was dried to constant weight at $105 \pm 3{ }^{\circ} \mathrm{C}$ and recorded as $\mathrm{W}_{2}$. The pectin content $\mathrm{P}_{1}$ was calculated according to the formula (1):

$$
P_{1}=\frac{W_{1}-W_{2}}{W_{1}} \times 100 \%
$$

The pectin removal rate was further calculated by the formula (2). In which, $R_{P}$ referred to pectin removal rate, $P_{1}$ referred to pectin content of degummed hemp fiber, and $P_{0}$ referred to pectin content of raw hemp fiber.

$$
R_{p}=1-\frac{P_{1}}{P_{2}} \times 100 \%
$$

The lignin of hemp fiber is a kind of aromatic polymer compounds, which is sTable to the effect of $\mathrm{H}_{2} \mathrm{SO}_{4}$, while the other components of hemp fiber are degradable in $\mathrm{H}_{2} \mathrm{SO}_{4}$. The lignin content was tested with this method.
Table 2. Plasma acid treatment process factors level

\begin{tabular}{|c|c|c|c|}
\hline No. & $\begin{array}{c}\mathrm{A} \\
\text { Liquor } \\
\text { ratio }\end{array}$ & $\begin{array}{c}\mathrm{B} \\
\text { Temperature: } \\
{ }^{\circ} \mathrm{C}\end{array}$ & $\begin{array}{c}\mathrm{C} \\
\text { Time: } \min \end{array}$ \\
\hline 1 & $1: 10$ & 20 & 30 \\
\hline 2 & $1: 20$ & 55 & 55 \\
\hline 3 & $1: 30$ & 90 & 80 \\
\hline
\end{tabular}

Each specimen weighed $1.2 \pm 0.010 \mathrm{~g}$ was tested 3 times. The samples were dried to constant weight at $105 \pm 3{ }^{\circ} \mathrm{C}$, and then the weight of the dried samples were tested and recorded as $\mathrm{W}_{3}$. Each sample was immersed into $15 \mathrm{ml} 72 \%$ $\mathrm{H}_{2} \mathrm{SO}_{4}$ at $20{ }^{\circ} \mathrm{C}$ and stirred once every $30 \mathrm{~min}$. After 4 h, $100 \mathrm{ml}$ distilled water was poured in. After $10 \mathrm{~h}$, the residue was obtained by filtering and dried to constant weight at $105 \pm 3{ }^{\circ} \mathrm{C}$. The weight of the residue was recorded as $\mathrm{W}_{4}$. The lignin content $\mathrm{L}_{1}$ was calculated according to the formula (3):

$$
L_{1}=\frac{W_{4}}{W_{3}} \times 100 \%
$$

The lignin removal rate was further calculated by the formula (4). $R_{L}$ referred to lignin removal rate, $L$, referred to lignin content of the degummed hemp fiber, and $L_{0}$ referred to lignin content of raw hemp fiber.

$$
R_{L}=1-\frac{L_{1}}{L_{0}} \times 100 \%
$$

\subsection{XRD analysis}

The crystalline structure of the untreated hemp and degummed hemp fiber were examined using a wide angle X-ray diffractometer (D /max-3B, Rigaku Co., Ltd., Japan). The samples were scanned from $2 \mathrm{u}$ D 10 50 with an opera ting voltage and current of $40 \mathrm{kV}$ and $200 \mathrm{~mA}$, respectively. The radiation was $\mathrm{Ni}$-filte red $\mathrm{Ka}$ radiation of wave-length $1.5406 \mathrm{~A}$.

\subsection{SEM analysis}

SEM was carried out using a JEOL JSM6460LV (Japan) to examine the fiber surface topography before and after treatments. Before examination, the fiber samples were sputter coated with a thin gold layer in a vacuum chamber.

\section{Results and discussion}

\subsection{Hemp degumming by plasma acid}

After plasma acid processing, the pectin and lignin content of hemp fiber were decreased significantly. The pectin removal rate and lignin removal rate were shown in Table 3.

The range analysis of the experimental data was shown in Table 4. In plasma acid degum- 
Table 3. The pectin removal rate and lignin removal rate.

\begin{tabular}{|c|c|c|c|c|c|}
\hline No. & $\mathrm{A}$ & $\mathrm{B}$ & $\mathrm{C}$ & $\begin{array}{c}\text { Pectin removal } \\
\text { rate(\%) }\end{array}$ & Lignin removal rate (\%) \\
\hline 1 & $1: 30$ & 90 & 30 & 53.966 & 43.55 \\
\hline 2 & $1: 10$ & 55 & 80 & 54.659 & 43.16 \\
\hline 3 & $1: 30$ & 20 & 80 & 52.857 & 38.75 \\
\hline 4 & $1: 10$ & 90 & 55 & 57.644 & 43.02 \\
\hline 5 & $1: 20$ & 90 & 80 & 59.538 & 39.51 \\
\hline 6 & $1: 30$ & 55 & 55 & 47.478 & 39.68 \\
\hline 7 & $1: 20$ & 55 & 30 & 53.285 & 38.48 \\
\hline 8 & $1: 20$ & 20 & 55 & 49.354 & 34.59 \\
\hline 9 & $1: 10$ & 20 & 30 & 54.172 & 41.31 \\
\hline
\end{tabular}

Table 4. Range analysis of the experimental scheme optimization

\begin{tabular}{|c|c|c|c|c|}
\hline Items & Factor & $\mathrm{A}$ & $\mathrm{B}$ & $\mathrm{C}$ \\
\hline \multirow{6}{*}{$\begin{array}{c}\text { Pectin } \\
\text { removal rate(\%) }\end{array}$} & $\mathrm{k} 1$ & 55.492 & 52.128 & 53.808 \\
\hline & $\mathrm{k} 2$ & 54.059 & 51.807 & 51.492 \\
\hline & $\mathrm{k} 3$ & 51.434 & 57.049 & 55.685 \\
\hline & Range & 4.058 & 5.242 & 4.193 \\
\hline & Optimization & $\mathrm{A} 1$ & B3 & C3 \\
\hline & Importance rank & \multicolumn{3}{|c|}{$\mathrm{B}>\mathrm{C}>\mathrm{A}$} \\
\hline \multirow{6}{*}{$\begin{array}{l}\text { Lignin } \\
\text { removal rate(\%) }\end{array}$} & $\mathrm{k} 1$ ' & 42.50 & 38.22 & 41.11 \\
\hline & $\mathrm{k} 2$ & 37.53 & 40.44 & 39.10 \\
\hline & k3' & 40.66 & 42.03 & 40.47 \\
\hline & Range & 4.97 & 3.81 & 2.01 \\
\hline & Optimization & $\mathrm{A} 1$ & B3 & $\mathrm{C} 1$ \\
\hline & Importance rank & \multicolumn{3}{|c|}{$A>B>C$} \\
\hline
\end{tabular}

ming process, the pectin degraded. When processing temperature increased from $20{ }^{\circ} \mathrm{C}$ to 90 ${ }^{\circ} \mathrm{C}$, the effect of plasma acid was enhanced. According to the pectin removal rate, processing temperature and time were important factors. Under $1: 10,90^{\circ} \mathrm{C}$, and $80 \mathrm{~min}(\mathrm{~A} 1, \mathrm{~B} 3, \mathrm{C} 3)$ condition, the pectin removal rate was better.

During plasma acid treatment, lignin swelled and further dissolved, including aromatic ring fracture and molecular weight decrease. According to the lignin removal rate, the influence of processing time on plasma acid processing was little. As the processing time extended, the acidity of plasma acid decreased. Under $1: 10,90{ }^{\circ} \mathrm{C}$, and $30 \mathrm{~min}$ (A1 B3 C1) condition, the lignin removal rate was better.

In order to obtain the optimal scheme of plasma acid degumming process, experiments were carried out under (A1 B3 C1) and (A1 B3 C3) conditions respectively. The pectin removal rate and lignin removal rate were tested. According to the testing results, under (A1 B3 C3) condition, the effect of plasma acid was better. The pectin removal rate was $58.553 \%$ and lignin removal rate was $43.70 \%$, as shown in Tables 5.
Table 5. Results of validation experiments

\begin{tabular}{|c|c|c||}
\hline Itmes & $\begin{array}{c}\text { Pectin removal } \\
\text { rate (\%) }\end{array}$ & $\begin{array}{c}\text { Lignin } \\
\text { removal rate (\%) }\end{array}$ \\
\hline A1B3C1 & 56.524 & 42.30 \\
\hline A1B3C3 & 58.553 & 43.70 \\
\hline
\end{tabular}

\subsection{Hemp degumming by sulfuric acid}

Under the same condition (A1 B3 C3), hemp fiber treated by $\mathrm{H}_{2} \mathrm{SO}_{4}$ was carried out as a contrast experiment. After treatment, the pectin and lignin removal rate were tested and shown in Table 6. It illustrated that the pectin removal rate was $62.331 \%$, while the lignin removal rate was $26.08 \%$, which was significantly fewer than plasma acid degumming of $43.70 \%$.

\section{$3.3 \mathrm{XRD}$ results}

XRD patterns of plasma acid degummed hemp fiber and raw hemp fiber were shown in Fig. 2. As can be seen from the graph, the main characteristic absorption peaks in (a) and (b) were almost the same, which belonged to the cellulose I. This showed that the plasma acid almost had no damage to hemp fiber. In addition the crystallinity of hemp fiber was increased after this processing. 
Table 6. Comparison of plasma acid and sulfuric acid treatment

\begin{tabular}{|c|c|c|}
\hline Itmes & Pectin removal rate (\%) & Lignin removal rate (\%) \\
\hline sulfuric acid treatment & 62.331 & 26.08 \\
\hline plasma acid treatment & 58.553 & 43.70 \\
\hline
\end{tabular}

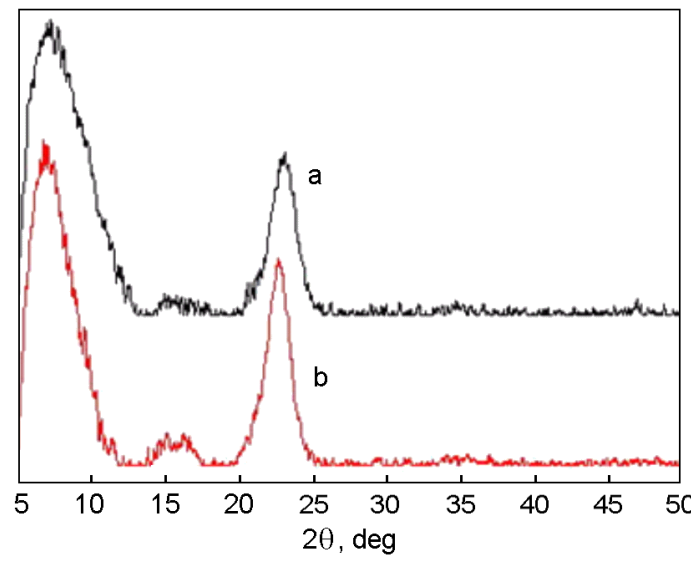

Fig. 2. The XRD patterns of hemp fibers. (a) raw hemp fiber and ( b) plasma acid treated hemp fiber.

\subsection{SEM results}

The SEM photographs of the surfaces of untreated and plasma-treated hemp fibers are shown in Fig. 3. From Fig. 3 (a), it is clear that the fibers, formed by fibrils glued together, were disposed in a multidirectional array. The diameters of single fibers were about $100 \mu \mathrm{m}$. SEM image also displayed a rougher surface with lots of waxy and gummy substances on the untreated hemp fiber. The internal fibrils also cannot be seen.

After plasma acid treatment, lots of single fibrils were clearly seen in the SEM image in Fig. 3(b). The waxy and gummy substances observed on the untreated hemp fibers surfaces had been removed. The inner fibrils were exposed following removal of the outer lignin.

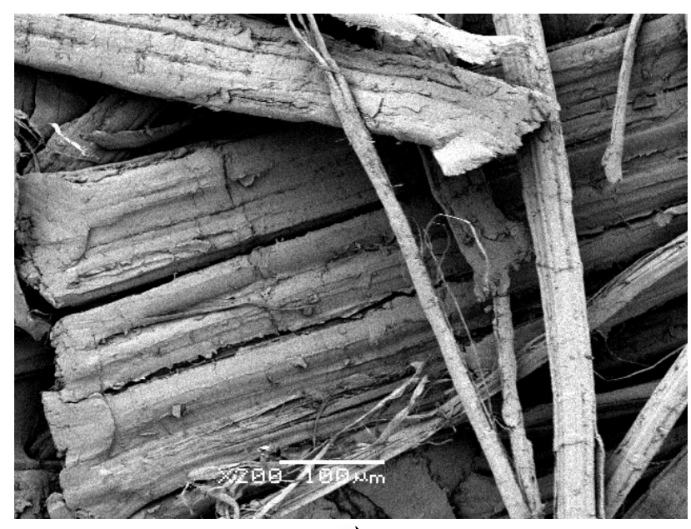

a)

Fig. 3. The SEM of hemp fibers. (a) raw hemp fiber and ( b) plasma acid treated hemp fiber.

\subsection{The created mechanics of plasma acid}

Previous reports [14-16] have shown that a large amount of oxygen species, including $\mathrm{O}$ atoms, $\mathrm{OH} \cdot$ radicals and $\mathrm{HO}_{2}$ radicals, were produced during the reaction of producing plasma species. Upon the $\mathrm{O}$ atom approaching a water molecule, the $\mathrm{O}$ atom abstracts a hydrogen atom from water and two $\mathrm{OH} \cdot$ radicals are created. Subsequently, one of the $\mathrm{OH}$ - radicals reacts with another water molecule resulting in the formation of a new water molecule and $\mathrm{OH} \cdot$ radical. This reaction extends the life expectancy of $\mathrm{OH} \cdot$ radicals and ensures them a long uses. But both reactions had no net effect to the plasma acid.

Eq.(5) illustrates the interaction of $\mathrm{HO}_{2}$ radicals with water; it is agreement with the literature that the $\mathrm{HO}_{2} \cdot$ radicals are a better proton donor but a weaker proton accepter than water It is clear that this reaction resulted in a hydrated proton $\mathrm{H}_{3} \mathrm{O}^{+}$. It is the plasma product in the liquid water that originally presented a strongly acidic feature which varied with the discharge conditions.

$\mathrm{HO}_{2}+\mathrm{H}_{2} \mathrm{O} \leftarrow \rightarrow\left[\mathrm{O}_{2}-\mathrm{H}-\mathrm{OH}_{2}\right] \leftarrow \rightarrow \mathrm{O}_{2}-+\mathrm{H}_{3} \mathrm{O}^{+}$

During the preparation of plasma acid, water molecules were dissociated into $\mathrm{H}_{2} \mathrm{O}$. Therefore, the plasma acid was active and effective in hemp degumming. The plasma acid in hemp degumming worked in three aspects. Firstly, pectin ester was degradated during plasma acid processing. Secondly, lignin was swelled and further dissolved, including aromatic ring fractured and the molecular weight decreased,

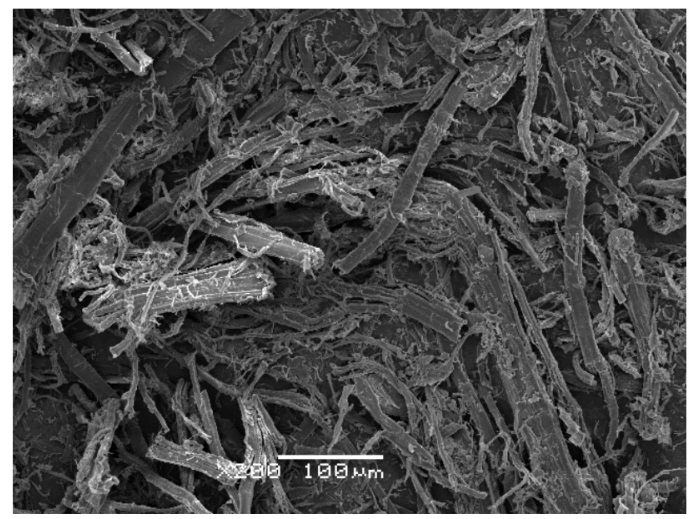


but no structural change. Lastly, hemicellulose glycosidic bond was cracked and hydrolysised by plasma acid. During the generation process of plasma acid, there was less pollution to the environment. And it is more to note that after several hours, the acidity of plasma acid would fade itself under room temperature.

\section{Conclusions}

The preparation of plasma acid was done place by processing distilled water with the help of dielectric barrier discharge device under atmospheric pressure. Compared with $\mathrm{H}_{2} \mathrm{SO}_{4}$ processing, plasma acid was of less pollution to the environment. In plasma acid degumming process, bath ratio, temperature and processing time were main factors. Under the optimal scheme of bath ratio $1: 10$, temperature $90{ }^{\circ} \mathrm{C}$, and processing time $80 \mathrm{~min}$, the pectin content was decreased to $58.553 \%$, and the lignin content was decreased to $43.70 \%$. The results of the pectin and lignin removal rate tests revealed that the plasma acid processing was effective in hemp degumming. Furthermore, the facilities and instruments required were easy to operate and low cost. Plasma acid provided a green acidic condition. Therefore the application of plasma acid on degumming hemp was effective and promising.

\section{Acknowledgements}

This work was financially supported by National Engineering Research Center of Seafood (2012FU125X03); Key University Science and Technology Platform of Liaoning Province (No. 2011-191); Liaoning province colleges' outstanding talent support program (No.LJQ2015008).

\section{References}

1. Michael Carus. J. Ind. Hemp., 12(1), 89, 2007.

2. Lea Turunen, Hayo M. G. van der Werf. J. Ind Hemp, 12(2),43, 2007.

3. Ji Ying-chao, Wang Ying, Wang Fei, Adv.Mater. Processes Techn., 217-219, 586, 2012.

4. Ji Ying-chao, Wang Fei, Adv. Compos. Mater, 482-484, 2531, 2012.

5. Ji Ying-chao, Liang Yu-jia, Adv.Mater. Processes Techn., , 217-219, 988, 2012.

6. U. Kogelschatz. . Plasma Chem. Plasma Process., 23(1), 1, 2003.

7. B. Jiang, J. Zheng, S. Qiu, M. Wu, Q. Zhang, Z. Yan and Q. Xue, Chem. Eng. J., 236, 348, 2014.

8. P. Baroch, N. Satio and O Takai, J. Phys. D: Appl. Phys., 41, 085207 (1-6), 2008.

9. R. P. Joshi, S. M. Thagard, Plasma Chem.Plasma Process., 33, 1, 2013.

10. R. P. Joshi and S. M. Thagard, Plasma Chem. Plasma Process., 33, 17, 2013.

11. M. Tichonovas, E. Krugly, V. Racys, et al., Chem. Eng. J., 229, 9, 2013.

12. G. Chen, M. Zhou, S. Chen and W. Chen, J. Hazard. Mater., 172, 786, 2009.

13. Y. Wang, B. Yuan, Y. C. Ji and H. Li, Carbohyd. Polym., l 97, 518, 2013.

14. C.Lee, Y. Na, T. Hong, E. Choi, et al., Appl. Phys. Lett., 105, 073702, 2014.

15. M. Yusupov, E. Neyts, P. Simon, et al., J. Phys. D Appl. Phys., 47, 025205, 2014.

16. C. Liu, J. Zou, J. Tianjin Univ. (in Chinese), 37, 189, 2004. 